\title{
Endoribonuclease Gene
}

National Cancer Institute

\section{Source}

National Cancer Institute. Endoribonuclease Gene. NCI Thesaurus. Code C25954.

Endoribonuclease Genes encode hydrolytic Endoribonucleases that hydrolyse internal ribonucleotide bonds of polynucleotides to yield olig onucleotides. (NCI) 